\title{
Gene expression profiling reveals distinct features of various porcine adipose tissues
}

Chaowei Zhou, Jie Zhang, Jideng Ma, Anan Jiang, Guoqing Tang, Miaomiao Mai, Li Zhu, Lin Bai, Mingzhou Li ${ }^{*}$ and Xuewei Li

\begin{abstract}
Background: The excessive accumulation of body fat is a major risk factor to develop a variety of metabolic diseases. To investigate the systematic association between the differences in gene expression profiling and adipose deposition, we used pig as a model, and measured the gene expression profiling of six variant adipose tissues in male and females from three pig breeds which display distinct fat level.
\end{abstract}

Results: We identified various differential expressed genes among breeds, tissues and between sexes, and further used a clustering method to identify sets of functionally co-expression genes linked to different obesity-related phenotypes. Our results reveal that the subcutaneous adipose tissues mainly modulate metabolic indicators, nonetheless, the visceral adipose tissues as well as the intermuscular adipose tissue were mainly associated with the impaired inflammatory and immune response.

Conclusions: The present study provided the evidence of gene expression profiling that the subcutaneous adipose tissues are mainly affected the metabolism process, whereas the visceral and intermuscular adipose tissues should been term as the metabolic risk factors of obesity.

Keywords: Gene expression profiling, Subcutaneous adipose tissues, Visceral adipose tissues, Pig

\section{Background}

Obesity is becoming a major global health hazard mainly because of the increased ingestion of high energy food and the decreased amounts of physical activity in populations. A gain in the adipose mass in the body is generally accompanied by increased risk of metabolism-related diseases. However, it is not only the amount of body fat mass, but also the distribution of adipose tissue that is now recognised as an important predictor of metabolic abnormalities.

Based on their anatomical location, adipose tissue can be divided into two major types: visceral adipose tissue (VAT) and subcutaneous adipose tissue (SAT). The VAT is a higher risk factor for obesity than SAT [1]. In particular, basal free fatty acid flux, lipolysis rate, and secretory protein expression are markedly higher in visceral adipocytes compared with subcutaneous adipocytes [2]. Our previous reports have provided epigenetic evidence that VAT is mainly associated with impaired

\footnotetext{
* Correspondence: mingzhou.li@163.com; xuewei.li@sicau.edu.cn Institute of Animal Genetics \& Breeding, College of Animal Science \& Technology, Sichuan Agricultural University, Ya'an, Sichuan 625000, China
}

inflammatory and immune responses and is a metabolic risk factor of obesity, while SAT is mainly associated with metabolic processes [3,4]. In addition, ethnic group and gender are important factors that affect adipose deposition $[5,6]$.

Pig (Sus scrofa) has been recognised as an attractive biomedical model for human because its physiology and anatomy are remarkably similar to humans and pigs are easy to breed and handle [7]. Here, we present a comprehensive genome-wide comparison of gene expression profiling among six adipose tissues from different body sites in both sexes of three well-defined pig breeds displaying distinct adipose phenotypes. Using microarray technology, we identified various differentially expressed genes that may be related to the different adipose deposition phenotypes among the breeds, and between the sexes and anatomic locations. We also used a clustering method to identify sets of co-expressed genes that may be functionally linked to different obesity-related phenotypes. These results can be used to understand the different accumulation mechanisms of the distinct adipose tissue types. 


\section{Results and discussion}

\section{Obesity-related phenotypes}

Our previous report based on same individuals have demonstrated that the adipose volume were significant difference among adipose tissues and breeds, and between sexes [3]. In addition, the 24 kinds of reprehensive metabolism indicators in serum also revealed the same ranking from the leaner Landrace, the wild Tibetan and the fatty Rongchang pigs [3].

\section{Identification of differentially expressed (DE) genes and relatedness of adipose samples}

The number of DE genes $(P<0.05$, three-way repeatedmeasures analysis of variance [ANOVA]) was lowest between male and female $(1,225)$, higher among different adipose tissues $(2,750)$, and highest among the different breeds $(2,949)$, indicating significant biological differences between the groups in the latter two categories (Figure 1A). To further characterise variability in the gene expression profiling, we performed a principal components analysis (PCA) based on the DE genes in each of the compared groups. The six adipose tissues clustered into two groups, VATs and SATs, which reflected their distinct functional and metabolic features (Figure 1B). Interestingly, the intermuscular adipose (IAD) tissue that is deposited between muscle bundles, clustered with the VATs in terms of gene expression profiling, suggesting that IAD may be a potential new risk factor for obesity-related diseases, in agreement with our findings from a previous study on methylation [4].

Although the three pig breeds clustered into three groups, the Rongchang and Tibetan breeds were closer to each other than the Landrace breed (Figure 1C). These results not only reflect the marked phenotypic differences in adipose deposition among the three pig breeds which have undergone different/opposite breeding directions, but also highlight the deep phylogenetic split between the European (Landrace) and Asian pigs (Rongchang and Tibetan) [3].

In addition, the male and female were also been roughly distinguish (Figure 1D), which consisted with the lowest variation of gene expression profiling between sexes, which only have less than half of the amount of DE genes than among tissue types and breeds.

\section{DE genes between the VATs and SATs}

The PCA classified six adipose tissues into two groups: the VAT group which included greater omentum adipose (GOM), mesenteric adipose (MAD), retroperitoneal adipose (RAD) and IAD; and the SAT group which included upper layer of backfat (ULB) and inner layer of backfat (ILB).

We performed a pairwise comparison analysis and identified 192 and $181 \mathrm{DE}$ genes that were specifically upregulated in the SAT and VAT groups, respectively (Figure 2

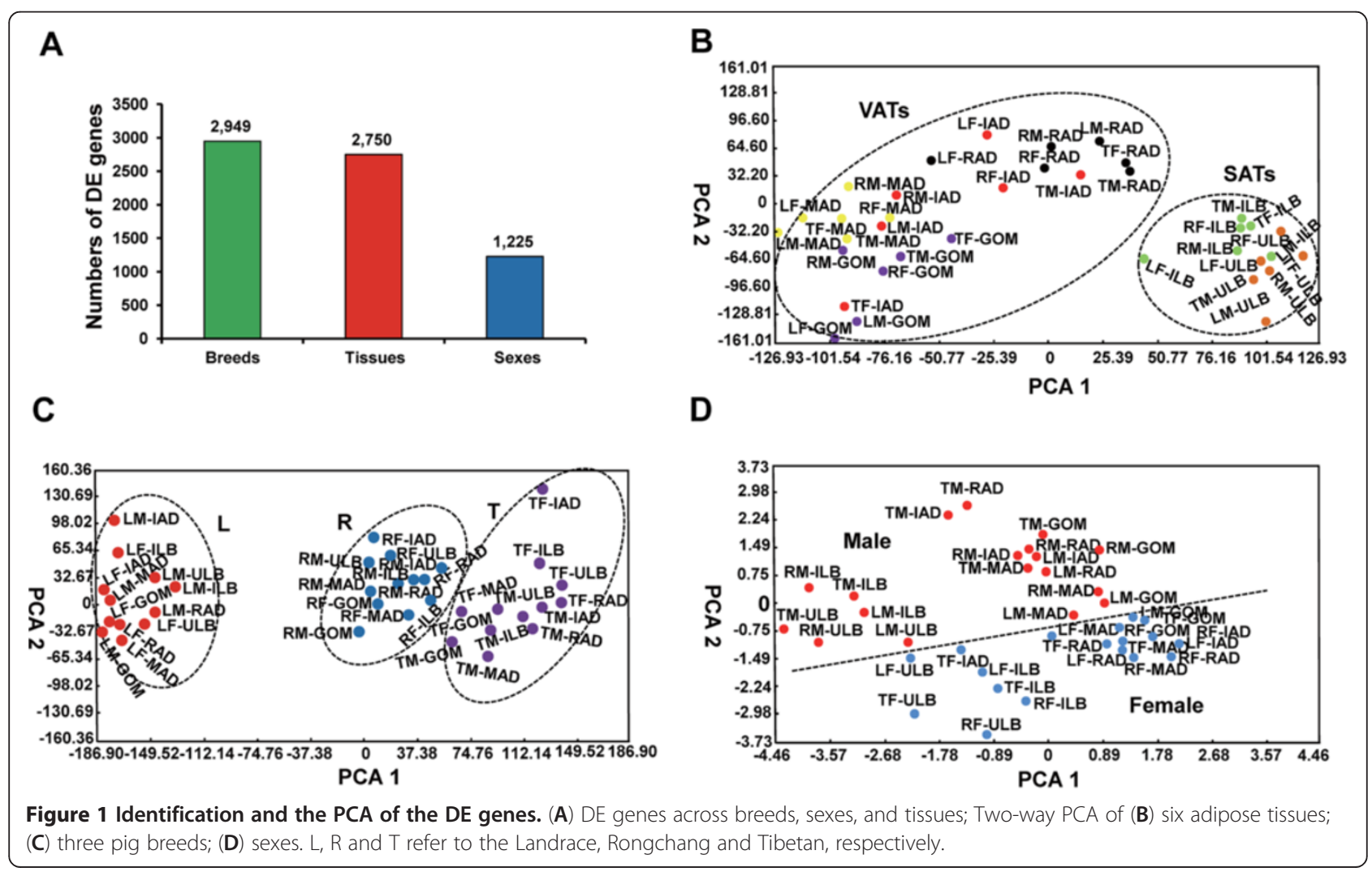




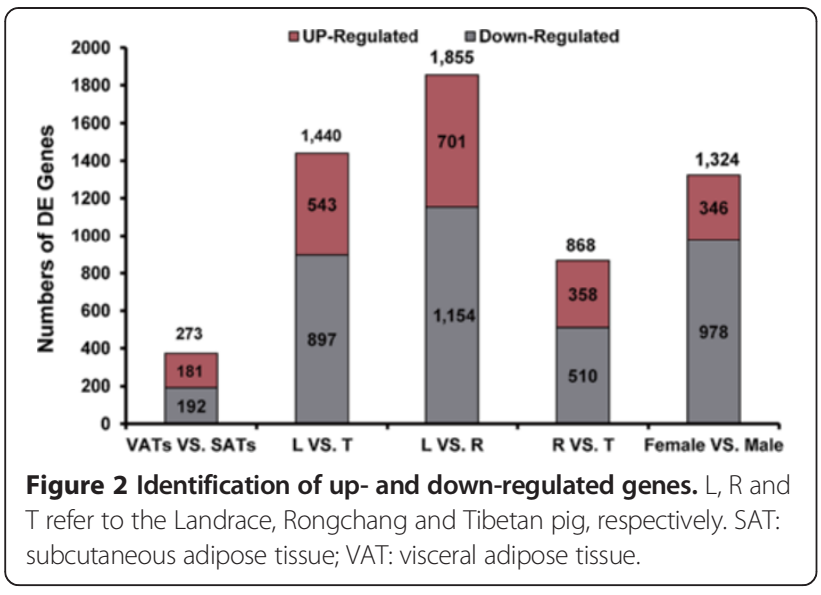

and Table 1). The DE genes which were specifically upregulated in the VAT group were mainly enriched in the $\mathrm{GO}$ categories of the immune processes, including positive regulation of defence response ( 8 genes, $\left.P=5.63 \times 10^{-4}\right)$, positive regulation of immune system process (10 genes, $P=1.11 \times 10^{-4}$ ), adaptive immune response (6 genes, $P=$ $\left.3.54 \times 10^{-4}\right)$, innate immune response ( 7 genes, $P=7.86 \times$ $10^{-4}$ ) and B cell mediated immunity (5 genes, $P=9.91 \times$ $10^{-4}$ ) (Figure 3). Various genes known to be involved in the immune response were highly expressed in VATs compared with in SATs $(P<0.05)$. For example, $C 3$ (complement 3 ), which was reported to play a central role in the activation of the complement system $[8,9]$ was upregulated in the VATs. CLEC12B (C-type lectin domain family $12 B$ ) limits the activity of monocyte-derived immune cells after cell differentiation and possibly during inflammatory diseases [10] (Figure 4). The action of these genes which were highly expressed in VATs may contribute to the obesity-induced chronic inflammation in adipose tissue that precedes the development of insulin resistance and type II diabetes.

The DE genes that were specifically up-regulated in the SAT group were mainly enriched in the GO

Table 1 Identification of DE genes which specifically up-regulated in SAT and VAT groups

\begin{tabular}{lcc}
\hline Libraries & Up-regulated genes & Down-regulated genes \\
\hline ULB VS. GOM & 298 & 378 \\
\hline ULB VS. MAD & 304 & 291 \\
\hline ULB VS. RAD & 164 & 142 \\
\hline ULB VS. IAD & 154 & 163 \\
\hline ILB VS. GOM & 286 & 302 \\
\hline ILB VS. MAD & 260 & 222 \\
\hline ILB VS. RAD & 73 & 60 \\
\hline ILB VS. IAD & 84 & 119 \\
\hline Specific expression genes & $192(>4) *$ & $181(>4) *$ \\
\hline
\end{tabular}

*: if a DE gene were identified from at least four comparisons, which been termed as the tissue- specific DE gene. categories of metabolic processes, including glucose metabolic process (6 genes, $P=1.16 \times 10^{-2}$ ), hexose metabolic process (6 genes, $P=2.81 \times 10^{-2}$ ), fatty acid metabolic process (6 genes, $P=3.15 \times 10^{-2}$ ) and monosaccharide metabolic process (6 genes, $P=4.77 \times 10^{-2}$ ) (Figure 3). This result is consistent with previous reports that, compared with the high-risk of visceral obesity caused by VATs, SATs are mainly associated with metabolic processes $[4,11]$.

\section{DE genes among the three pig breeds}

The number of DE genes $(P<0.05$, three-way repeatedmeasures ANOVA) was highest between the fatty Rongchang and leaner Landrace pigs $(1,855)$, lower between the wild Tibetan and Landrace pigs $(1,440)$, and lowest between the Tibetan and Rongchang pigs (868) (Figure 2).

The highly expressed genes in the Landrace pigs were mainly involved in the GO and KEGG categories of skeletal system development processes and immune processes, including positive regulation of skeletal system development (7 genes, $P=2.22 \times 10^{-4}$ ), bone development ( 8 genes, $P=4.16 \times 10^{-2}$ ), positive regulation of immune system process (20 genes, $\left.P=1.19 \times 10^{-3}\right)$ and adaptive immune response ( 8 genes, $P=2.39 \times 10^{-2}$ ) (Figure 5). The highly expressed genes in the Rongchang pigs were mainly involved in the processes of lipid metabolism and immune processes, such as lipid oxidation (8 genes, $P=1.40 \times 10^{-3}$ ), fatty acid oxidation (8 genes, $\left.P=2.53 \times 10^{-3}\right)$, fatty acid metabolic process (21 genes, $P=4.71 \times 10^{-4}$ ), activation of immune response (6 genes, $P=$ $\left.1.30 \times 10^{-2}\right)$ and positive regulation of immune response (8 genes, $P=5.93 \times 10^{-3}$ ). This result reflects the phenotypic divergence of adipose deposition between these two pig breeds that have undergone artificial selection for different breeding targets. The Landrace breed is under strong artificial selection for more muscle production, while the Rongchang breed is selected for more adipose deposition.

\section{DE genes between the sexes}

Almost three-quarters of the $\mathrm{DE}$ genes between the sexes (879 of $1,225,71.76 \%)$ were up-regulated in the males (Figure 2). These highly expressed genes were enriched mainly in the GO categories of the immune processes (Figure 6), including positive regulation of immune system process (28 genes, $P=4.49 \times 10^{-6}$ ), adaptive immune response (11 genes, $P=1.71 \times 10^{-3}$ ), humoral immune response ( 7 genes, $\left.P=1.86 \times 10^{-3}\right)$, immunoglobulin mediated immune response ( 9 genes, $P=2.09 \times$ $\left.10^{-3}\right)$, regulation of acute inflammatory response (5 genes, $P=1.15 \times 10^{-2}$ ) and immune effector process (13 genes, $P=1.33 \times 10^{-2}$ ). The $\mathrm{DE}$ genes (346 of 1,225 , $28.24 \%$ ), which were up-regulated in the females 


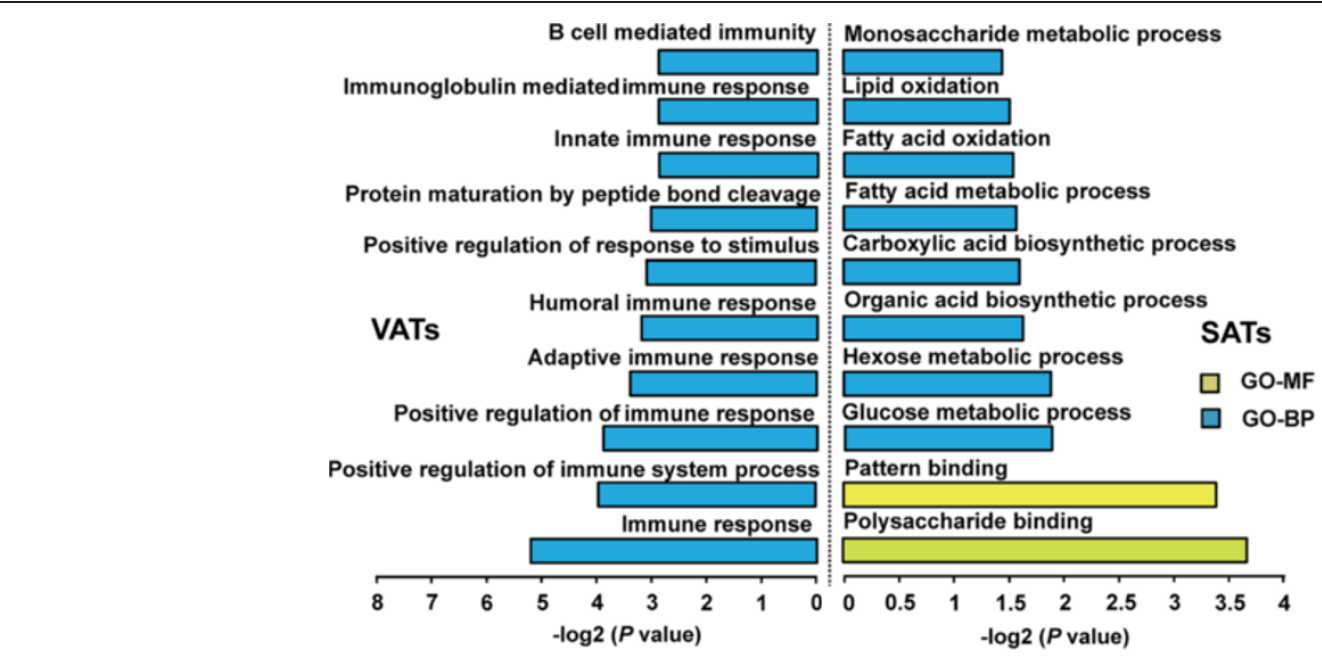

Figure 3 Top ten GO (Gene Ontology) terms enriched for the up- and down-regulated genes between the SATs and VATs. The $p$ values indicated the significance of the comparison, was calculated by Benjamini-corrected modified Fisher's exact test.

(Figure 2), were mainly involved in metabolic processes (Figure 6), including the coenzyme metabolic process (10 genes, $P=1.08 \times 10^{-3}$ ), cofactor metabolic process (11 genes, $P=1.64 \times 10^{-3}$ ), oxidoreduction coenzyme metabolic process (5 genes, $P=1.54 \times 10^{-2}$ ) and organic acid biosynthetic process $\left(8\right.$ genes, $\left.P=1.10 \times 10^{-2}\right)$. This result reflects a sexual dimorphism in body fat distribution [12]. Females deposit relatively more fat in subcutaneous/inguinal depots, which has beneficial effects on the control of body weight and metabolism [13]; on the other hand, males tend to deposit more fat in intraabdominal/gonadal depots, which has been found to be related to risk for a number of diseases [14].

Interestingly, we identified some genes that potentially contribute to the sexual differences in obesity development. Compared with the females, the males exhibited higher expression levels of RXFP2 $\left(P=1.19 \times 10^{-13}\right)$ and
CPB1 $\left(P=5.69 \times 10^{-6}\right) \quad$ (Figure 7$)$, which have been related to gubernaculum testis development and spermatogenesis $[15,16]$. However, compared with the males, the females exhibited higher expression levels of $P A E P$ $\left(P=3.71 \times 10^{-5}\right)$ and FABP7 $\left(P=8.42 \times 10^{-9}\right)$ (Figure 7$)$, which have been associated mainly with the secretory endometrial glands and breast cancer $[17,18]$.

\section{Validation of gene expression changes by Q-PCR}

The expression changes of nine genes that are wellknown to be related to adipose metabolism ( $A C A D L$, ADIPOQ, ADIPOR 1, CAV 3, MDH 1, MDH 2, ME 1, Insig 1 and $S C A P$ ) showed significant positive correlations between the Q-PCR results and their expressions determined by microarray $(P<0.05$, Figure 8$)$, which highlighted the high confidence of the results from the microarray approach.
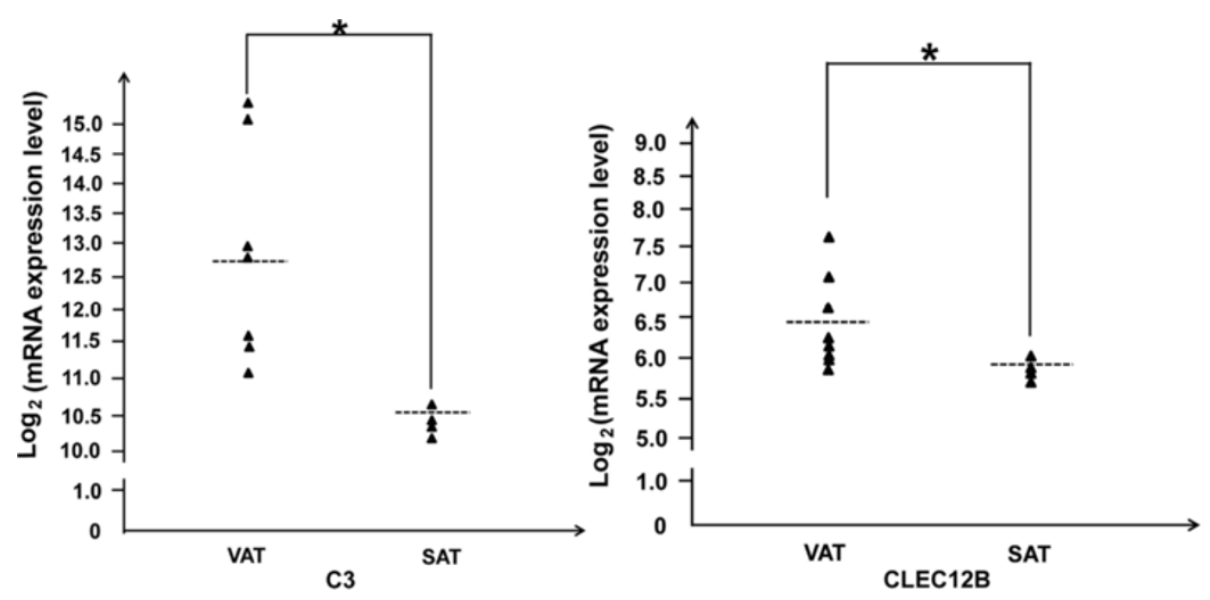

Figure 4 Differences in mRNA expression levels of the $C 3$ and CLEC12B gene between the VATs and SATs. 
A

L VS. R (GO and Pathway)

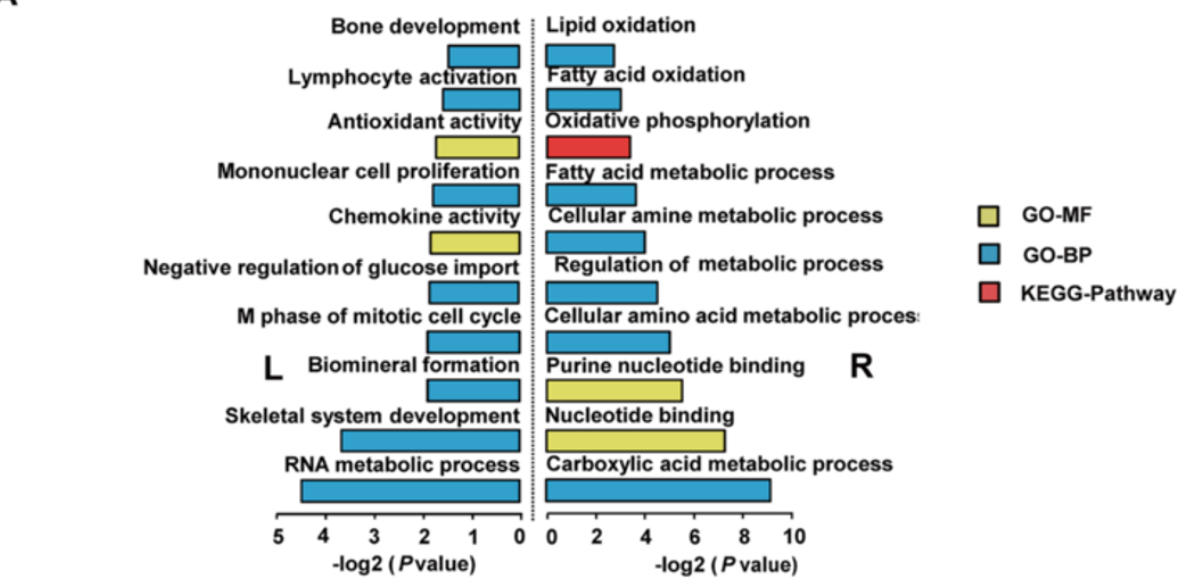

B

L VS. T (GO and Pathway)

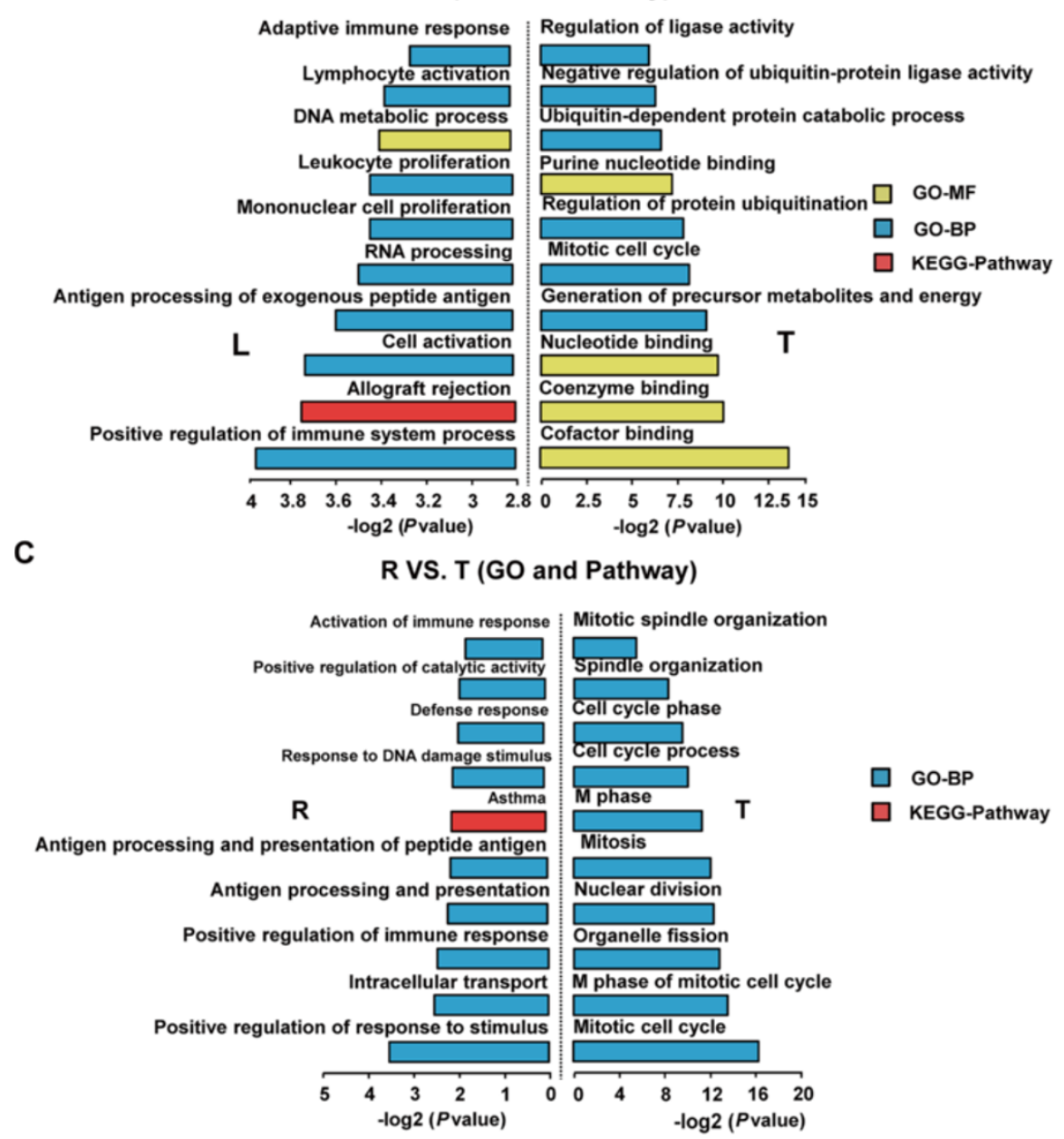

Figure 5 Top ten GO (Gene Ontology) terms enriched for the up- and down-regulated genes among the three pig breeds. (A) The Landrace versus Rongchang pig; (B) The Landrace versus Tibetan pig; (C) The Rongchang versus Tibetan pigs. The $P$ values indicated the significance of the comparison, was calculated by Benjamini-corrected modified Fisher's exact test. 


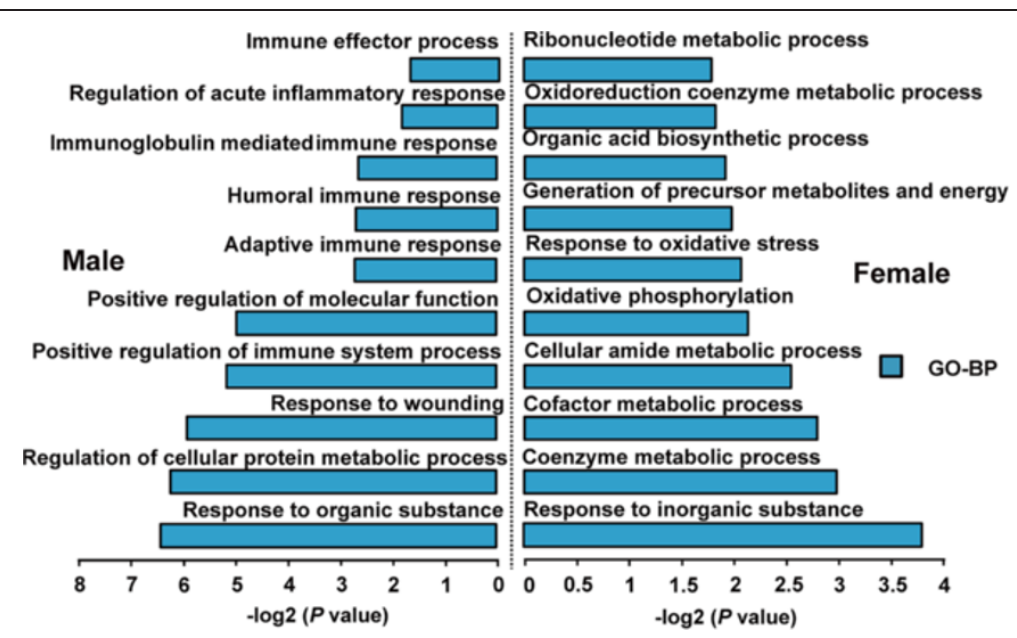

Figure 6 Top ten GO (Gene Ontology) terms enriched for the up- and down-regulated genes between the male and female pig breeds. The $p$ values indicated the significance of the comparison, was calculated by Benjamini-corrected modified Fisher's exact test.
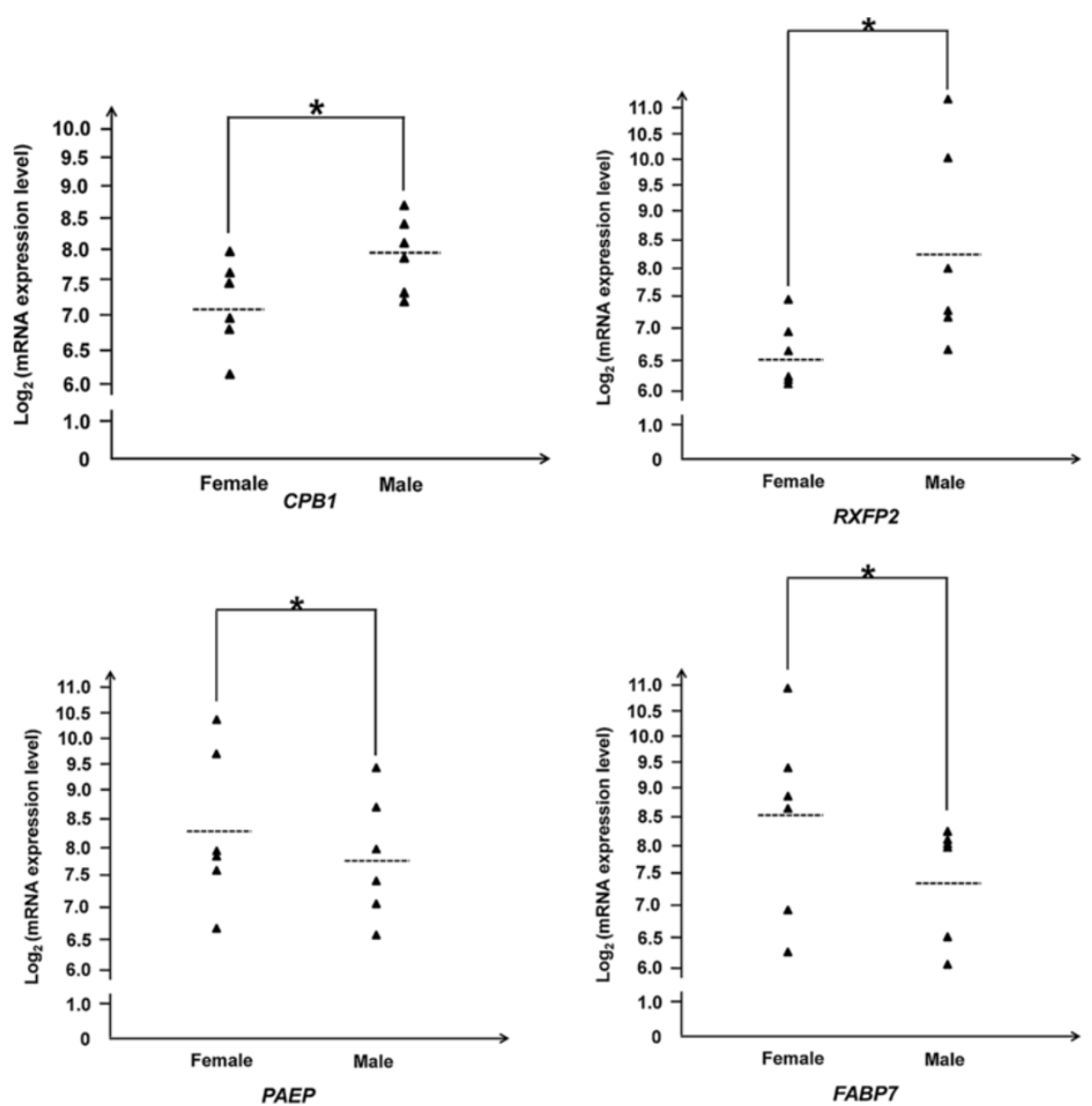

Figure 7 Differences in mRNA expression levels of the CPB1, RXFP2, PAEP and FABP7 gene between the between the females and males. 


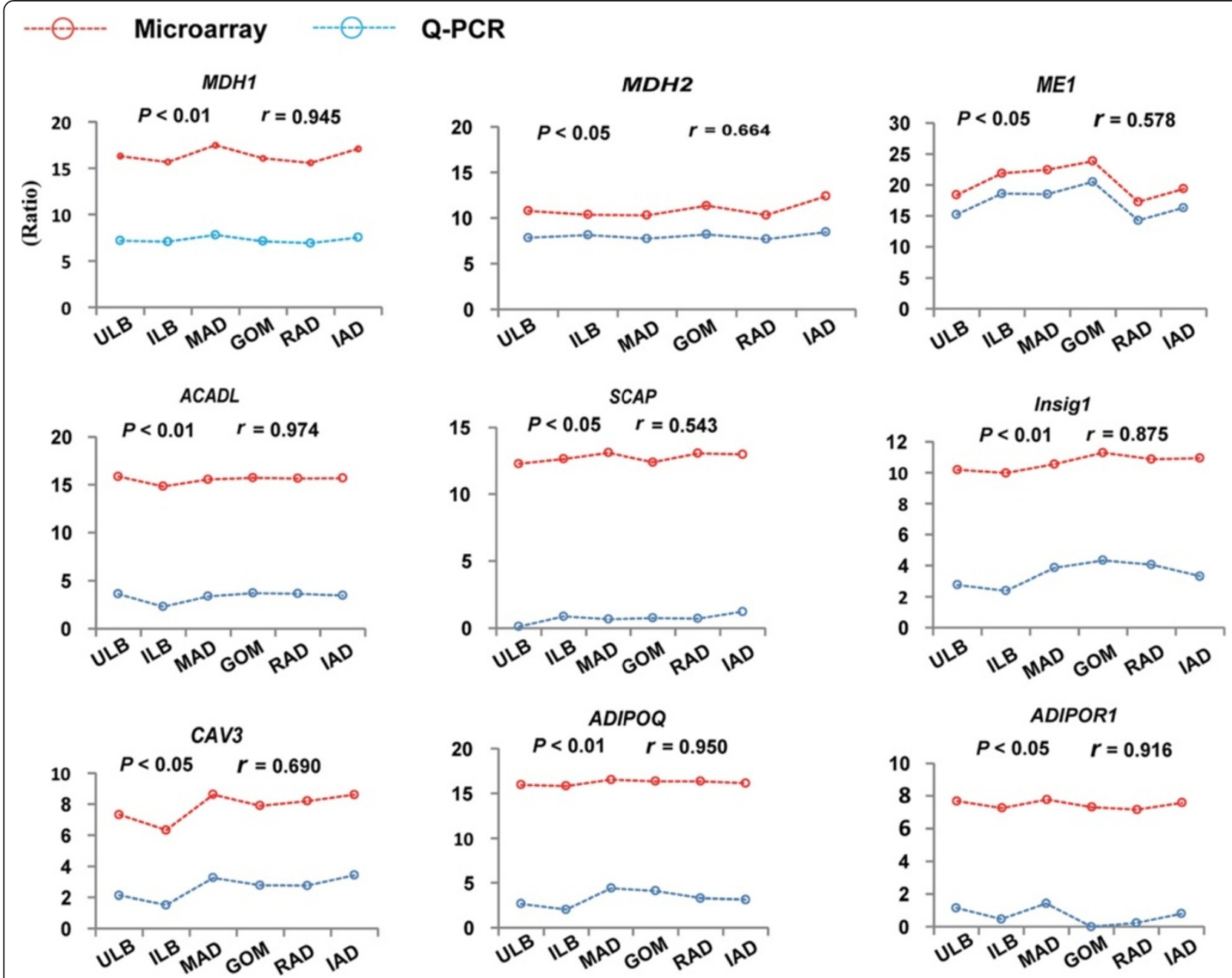

Figure 8 Validation of gene expression by Q-PCR. The Pearson correlation coefficient $(r)$ and the corresponding significance value $(P)$ were shown above the columns.

\section{Co-expressed gene sets linked to the obesity-related phenotypes}

Generally, quantitative characters (such as adipose deposition) in mammals are determined by a set of genes that cooperate in certain biological processes [11]. To further explore the relationships between the genes and obesity-related traits, we applied a clustering method to identify sets of functionally related genes linked to the phenotypic traits as reported previously [19].

We identified eight gene modules containing 947 genes for ULB and twelve gene modules containing 1,277 genes for ILB. In three typical VATs, we identified nine, nine and eleven gene modules containing 933, 1,058 and 1,409 genes for the MAD, GOM and RAD tissues, respectively. For the IAD, we identified eleven modules containing 1,423 genes (Figure 9).

Next, we explored the correlations between the modules of co-expressed genes and the various obesity phenotypes. Three gene modules in the SATs (i.e. ULB and
ILB) were significantly correlated with adipocyte volume and the concentration of plasma lactate dehydrogenase in serum (false discovery rate adjusted permutation, $P<0.05$ ) (Figure 10 and Table 2). The co-expressed genes within these modules were mainly involved in metabolic processes, such as fatty acid metabolic process (23 genes, $\left.P=4.38 \times 10^{-5}\right)$, fatty acid beta-oxidation (3 genes, $P=$ $2.65 \times 10^{-3}$ ), coenzyme metabolic process (6 genes, $P=4.77 \times 10^{-5}$ ) and carbohydrate metabolic process (12 genes, $P=2.94 \times 10^{-3}$ ) (Table 3), in agreement with an earlier report that SATs contribute mainly to metabolic processes $[20,21]$.

The co-expressed genes in two of the VATs (i.e. GOM and MAD) mainly affected the concentrations of inflammatory and immune adipokines in serum, i.e. plasminogen activator inhibitor-1 (PAI-1), interleukin 6 (IL-6) and tumor necrosis factor- $\alpha$ (TNF- $\alpha$ ) (Figure 10 and Table 2). The co-expressed genes within these modules were mainly involved in immune system process (21 


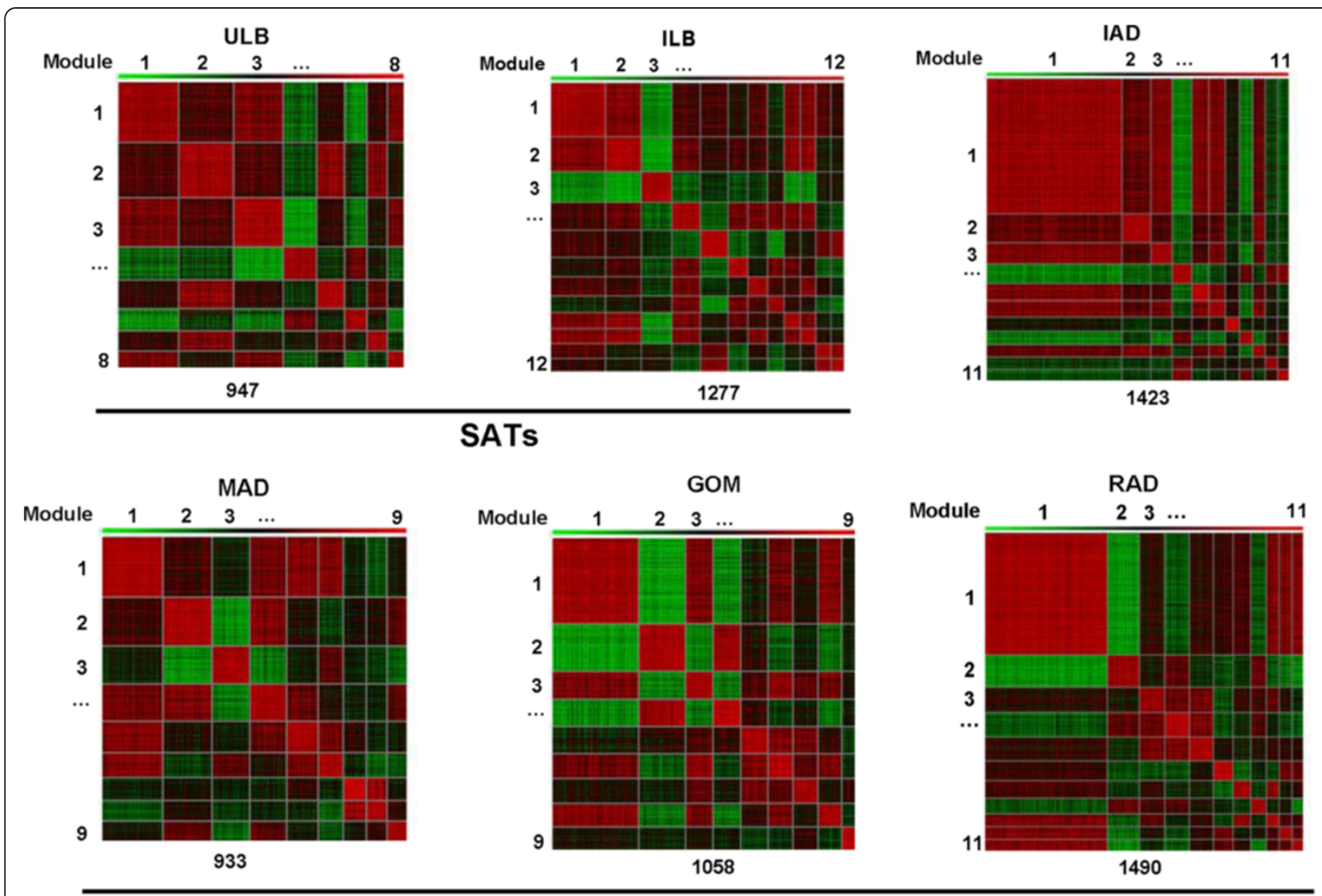

\section{VATs}

Figure 9 Heat maps of co-expressed gene modules in six adipose tissues. Two SATs (ILB: inner layer of backfat, ULB: upper layer of backfat); three VATs (GOM: greater omentum, MAD: mesenteric adipose, RAD: retroperitoneal adipose); and intermuscular adipose (IAD). Pair-wise correlations between genes residing in all the gene sets were plotted. Bright red indicates a strong positive co-expression, whereas bright green indicates strong negative co-expression.

genes, $\left.P=6.66 \times 10^{-4}\right)$, immune response $(8$ genes, $P=$ $\left.6.84 \times 10^{-3}\right)$, cellular defence response (15 genes, $P=1.25 \times$ $\left.10^{-10}\right)$, cellular defence response (6 genes, $P=4.67 \times 10^{-3}$ ) and $\mathrm{B}$ cell mediated immunity (9 genes, $P=1.05 \times 10^{-7}$ ). This result suggested that the GOM and MAD tissues contributed mainly to the obesity-induced chronic inflammation in adipose tissue that precedes the development of insulin resistance and type II diabetes [22,23]. The RAD tissue, on the other hand, was found to affect mainly the body density and the concentrations of three metabolic indicators in serum, namely, high density lipoprotein, insulin, and apolipoprotein A-1 (Apo-A1), which are mainly involved in metabolic processes such as coenzyme metabolic process (16 genes, $P=3.02 \times 10^{-9}$ ), primary metabolic process (241 genes, $P=9.31 \times 10^{-9}$ ), and tricarboxylic acid cycle (7 genes, $P=5.49 \times 10^{-6}$ ) (Table 3). Studies in human showed that GOM was strongly correlated to insulin, while no such correlations were found between lipid uptake and SAT or RAD [24].

Similar to the findings for the high-risk VATs, the coexpressed genes in IAD were also found to be significantly correlated with immune-related TNF- $\alpha$ (Figure 10 and Table 2), further suggesting that the IAD is an independent risk factor for metabolic diseases [25].

\section{Conclusions}

The present study describes a genome-wide analysis of gene expression profiling among various adipose depots between the sexes of three well-defined pig breeds displaying distinct adipose phenotypes. We present evidence that the SATs mainly affect metabolic processes, while the VATs and the IAD are associated mainly with immune and inflammation responses that are seen as the metabolic risk factors of obesity. This study also supports pig as an ideal model for studying human obesity.

\section{Materials and methods}

\section{Tissue collection}

Three females and three males at 210-days-old for each of the leaner Landrace pigs (a Western breed), the wild Tibetan pigs (a feral, indigenous Chinese pig that has not undergone artificial selection) and the fatty Rongchang 


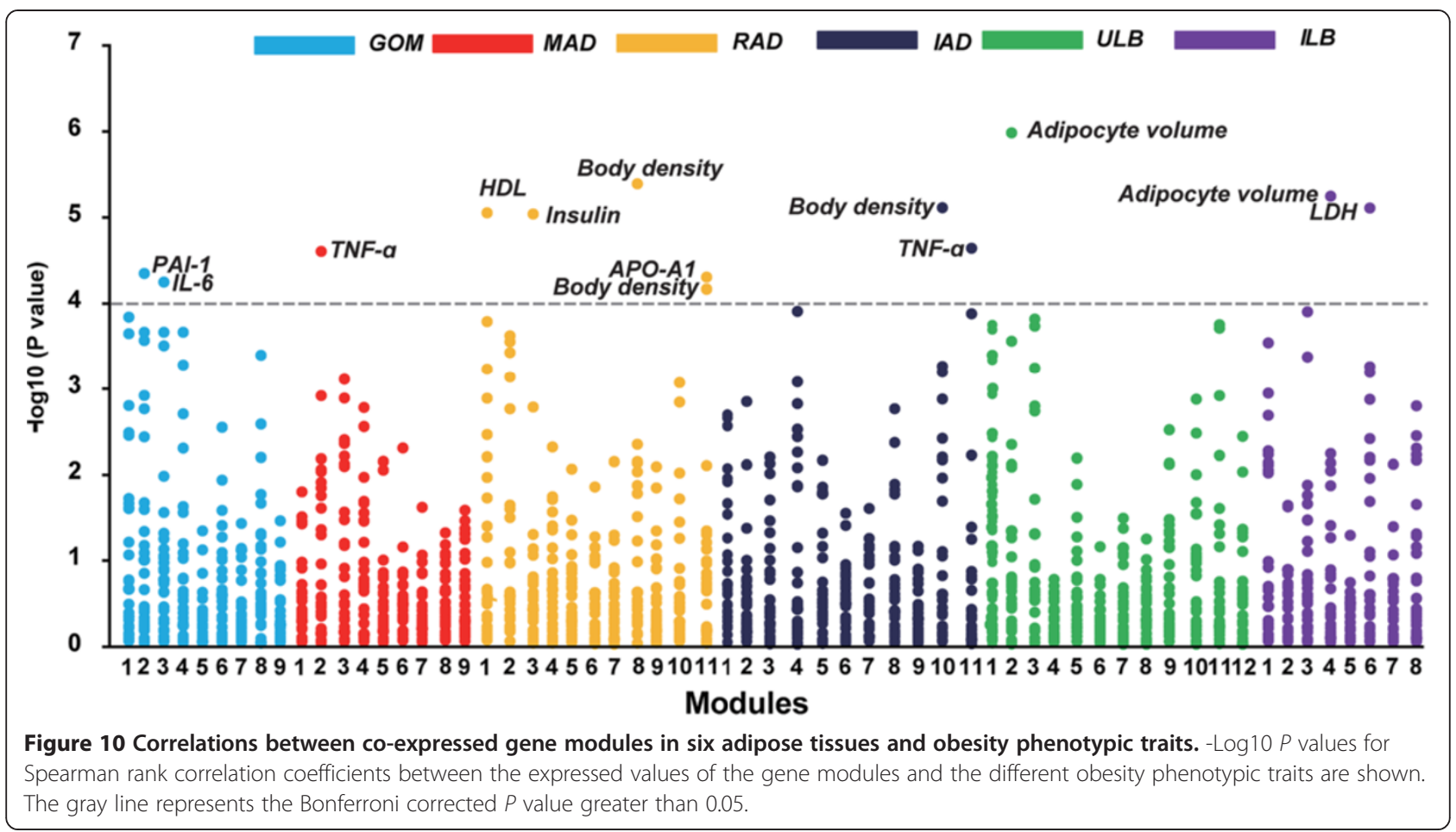

pigs (a Chinese breed) were used in this study as previously described [3]. Animals were humanely sacrificed, in compliance with experimental animals established by the Ministry of Agriculture of China. Three VATs (i.e. GOM, MAD and RAD), two SATs (i.e. ULB and ILB) as well as IAD were rapidly separated from each carcass, immediately frozen in liquid nitrogen, and stored at $-80^{\circ} \mathrm{C}$ until RNA extraction. For more information, please refer to Li et al. [3].

Measurements of the obesity-related phenotypes

Measurements of the pig body density, the concentrations of 24 serum-circulating indicators of metabolism and the adipocyte volume are from our previous report based on same individuals. For more information, please refer to Li et al. [3].

\section{RNA isolation and microarray analysis}

The total RNA $(10 \mu \mathrm{g})$ of the 108 tissue samples was extracted with TRIzol (Invitrogen) and further purified using an Rneasy column (Qiagen). Hybridization, washing, and scanning were done according to standard Agilent protocols. The data analysis was performed with MultiExperiment Viewer (MeV) [24]. Array data have been uploaded to NCBI's Gene Expression Omnibus

Table 2 Modules correlated with the obesity-related traits in SATs and VATs

\begin{tabular}{|c|c|c|c|c|c|c|}
\hline \multicolumn{2}{|c|}{ Tissues } & \multirow{2}{*}{$\frac{\text { Module ID }}{4}$} & \multirow{2}{*}{$\begin{array}{c}\text { Correlated trait } \\
\text { Adipocyte volume }\end{array}$} & \multirow{2}{*}{$\frac{\text { No. of genes in module }}{110}$} & \multirow{2}{*}{$\begin{array}{c}\text { Correlation coefficient } \\
-0.85\end{array}$} & \multirow{2}{*}{$\frac{P \text {-value }}{8.12 \times 10^{-6}}$} \\
\hline$\overline{\text { SAT }}$ & ULB & & & & & \\
\hline & & 6 & $\mathrm{LDH}$ & 72 & -0.84 & $1.23 \times 10^{-5}$ \\
\hline & ILB & 2 & Adipocyte volume & 157 & 0.87 & $2.05 \times 10^{-6}$ \\
\hline \multirow[t]{10}{*}{$\overline{\text { VAT }}$} & GOM & 2 & PAI-1 & 162 & -0.81 & $4.97 \times 10^{-5}$ \\
\hline & & 3 & IL-6 & 92 & -0.80 & $6.28 \times 10^{-5}$ \\
\hline & $\overline{M A D}$ & 2 & TNF-a & 152 & 0.82 & $2.57 \times 10^{-5}$ \\
\hline & $\overline{R A D}$ & 8 & Body density & 71 & 0.87 & $2.97 \times 10^{-6}$ \\
\hline & & 11 & Body density & 51 & -0.81 & $5.44 \times 10^{-5}$ \\
\hline & & 1 & $\mathrm{HDL}$ & 590 & 0.85 & $7.42 \times 10^{-6}$ \\
\hline & & 11 & Apo-A1 & 51 & -0.81 & $3.91 \times 10^{-5}$ \\
\hline & & 3 & Insulin & 118 & 0.77 & $6.89 \times 10^{-6}$ \\
\hline & $\overline{I A D}$ & 10 & Body density & 55 & 0.86 & $5.90 \times 10^{-6}$ \\
\hline & & 11 & TNF-a & 52 & -0.83 & $2.15 \times 10^{-5}$ \\
\hline
\end{tabular}


Table 3 Top ten GO (Gene Ontology) and pathway categories enriched for co-expressed gene modules which correlated with obesity phenotypic traits

\begin{tabular}{|c|c|c|c|c|c|}
\hline Correlated trait & $\begin{array}{c}\text { Tissue } \\
\text { (Gene sets order No.) }\end{array}$ & $\begin{array}{l}\text { Functional } \\
\text { category }\end{array}$ & Term & $P$ values & $\begin{array}{l}\text { Involved } \\
\text { gene No. }\end{array}$ \\
\hline \multirow[t]{10}{*}{ Adipocyte volume } & ULB (4) & GO-BP & metabolic process & $1.19 \times 10^{-7}$ & 119 \\
\hline & \multirow[t]{9}{*}{ ILB (2) } & GO-BP & coenzyme metabolic process & $8.84 \times 10^{-6}$ & 8 \\
\hline & & GO-BP & lipid metabolic process & $4.38 \times 10^{-5}$ & 23 \\
\hline & & GO-BP & fatty acid metabolic process & $8.95 \times 10^{-5}$ & 10 \\
\hline & & GO-BP & primary metabolic process & $1.07 \times 10^{-4}$ & 104 \\
\hline & & GO-BP & translation & $5.37 \times 10^{-4}$ & 12 \\
\hline & & GO-BP & protein folding & $1.50 \times 10^{-3}$ & 8 \\
\hline & & GO-BP & fatty acid beta-oxidation & $2.65 \times 10^{-3}$ & 3 \\
\hline & & GO-BP & pentose-phosphate shunt & $3.51 \times 10^{-3}$ & 2 \\
\hline & & GO-BP & generation of precursor metabolites and energy & $4.15 \times 10^{-3}$ & 9 \\
\hline \multirow[t]{10}{*}{ Body density } & $\operatorname{RAD}(8,11)$ & GO-BP & translation & $1.44 \times 10^{-3}$ & 8 \\
\hline & \multirow[t]{9}{*}{ IAD (10) } & GO-BP & protein targeting & $1.90 \times 10^{-3}$ & 5 \\
\hline & & GO-BP & lysosomal transport & $5.44 \times 10^{-3}$ & 2 \\
\hline & & GO-MF & structural constituent of ribosome & $6.10 \times 10^{-3}$ & 5 \\
\hline & & GO-MF & structural molecule activity & $6.62 \times 10^{-3}$ & 15 \\
\hline & & GO-BP & nitrogen utilization & $1.20 \times 10^{-2}$ & 1 \\
\hline & & KEGG & Serine glycine biosynthesis & $2.97 \times 10^{-2}$ & 1 \\
\hline & & GO-BP & regulation of amino acid metabolic process & $3.55 \times 10^{-2}$ & 1 \\
\hline & & GO-BP & pyrimidine base metabolic process & $4.40 \times 10^{-2}$ & 2 \\
\hline & & GO-BP & pentose-phosphate shunt & $4.71 \times 10^{-2}$ & 1 \\
\hline \multirow{10}{*}{$\begin{array}{c}\text { Apo-A1 } \\
\text { (Metabolic indicators) }\end{array}$} & \multirow[t]{10}{*}{ RAD (11) } & GO-BP & nitrogen utilization & $3.51 \times 10^{-3}$ & 1 \\
\hline & & GO-BP & regulation of amino acid metabolic process & $1.05 \times 10^{-2}$ & 1 \\
\hline & & GO-BP & lysosomal transport & $3.12 \times 10^{-2}$ & 1 \\
\hline & & GO-BP & nitrogen compound metabolic process & $3.12 \times 10^{-2}$ & 1 \\
\hline & & GO-BP & neuromuscular synaptic transmission & $4.64 \times 10^{-2}$ & 1 \\
\hline & & GO-MF & hormone activity & $1.55 \times 10^{-2}$ & 2 \\
\hline & & KEGG & Vasopressin synthesis & $2.09 \times 10^{-2}$ & 1 \\
\hline & & KEGG & De novo pyrmidineribonucleotidesbiosythesis & $3.12 \times 10^{-2}$ & 1 \\
\hline & & KEGG & Cortocotropin releasing factor receptor signaling pathway & $5.14 \times 10^{-2}$ & 1 \\
\hline & & KEGG & De novo purine biosynthesis & $5.64 \times 10^{-2}$ & 1 \\
\hline \multirow{10}{*}{$\begin{array}{l}\text { HDL (Metabolic } \\
\text { indicators) }\end{array}$} & \multirow[t]{10}{*}{$\operatorname{RAD}(1)$} & GO-BP & generation of precursor metabolites and energy & $1.20 \times 10^{-15}$ & 37 \\
\hline & & GO-BP & metabolic process & $1.49 \times 10^{-14}$ & 273 \\
\hline & & GO-BP & respiratory electron transport chain & $1.35 \times 10^{-11}$ & 30 \\
\hline & & GO-BP & coenzyme metabolic process & $3.02 \times 10^{-9}$ & 16 \\
\hline & & GO-BP & primary metabolic process & $9.31 \times 10^{-9}$ & 241 \\
\hline & & GO-BP & signal transduction & $6.95 \times 10^{-7}$ & 48 \\
\hline & & GO-BP & cell communication & $8.92 \times 10^{-7}$ & 52 \\
\hline & & GO-BP & cell surface receptor linked signal transduction & $1.49 \times 10^{-6}$ & 15 \\
\hline & & GO-BP & system development & $3.58 \times 10^{-6}$ & 9 \\
\hline & & GO-BP & tricarboxylic acid cycle & $5.49 \times 10^{-6}$ & 7 \\
\hline \multirow{7}{*}{$\begin{array}{l}\text { LDH (Metabolic } \\
\text { indicators) }\end{array}$} & \multirow[t]{7}{*}{ ULB (3) } & GO-BP & fatty acid metabolic process & $1.37 \times 10^{-5}$ & 9 \\
\hline & & GO-BP & metabolic process & $1.86 \times 10^{-5}$ & 75 \\
\hline & & GO-BP & fatty acid beta-oxidation & $3.05 \times 10^{-5}$ & 4 \\
\hline & & GO-BP & coenzyme metabolic process & $4.77 \times 10^{-5}$ & 6 \\
\hline & & GO-BP & cellular amino acid biosynthetic process & $9.01 \times 10^{-5}$ & 5 \\
\hline & & GO-BP & cellular amino acid metabolic process & $1.05 \times 10^{-4}$ & 9 \\
\hline & & GO-BP & protein folding & $4.66 \times 10^{-4}$ & 7 \\
\hline
\end{tabular}


Table 3 Top ten GO (Gene Ontology) and pathway categories enriched for co-expressed gene modules which correlated with obesity phenotypic traits (Continued)

\begin{tabular}{|c|c|c|c|c|c|}
\hline & & GO-BP & pentose-phosphate shunt & $1.45 \times 10^{-3}$ & 2 \\
\hline & & GO-BP & primary metabolic process & $1.99 \times 10^{-3}$ & 66 \\
\hline & & GO-BP & carbohydrate metabolic process & $2.94 \times 10^{-3}$ & 12 \\
\hline \multirow{10}{*}{$\begin{array}{l}\text { Insulin (Metabolic } \\
\text { indicators }\end{array}$} & \multirow[t]{10}{*}{ RAD (3) } & KEGG & VEGF signaling pathway & $3.72 \times 10^{-4}$ & 4 \\
\hline & & GO-BP & transcription, RNA-dependent & $4.06 \times 10^{-4}$ & 2 \\
\hline & & GO-BP & cell communication & $6.62 \times 10^{-4}$ & 31 \\
\hline & & GO-BP & mesoderm development & $1.04 \times 10^{-3}$ & 11 \\
\hline & & GO-BP & cellular process & $1.10 \times 10^{-3}$ & 40 \\
\hline & & $\mathrm{GO}-\mathrm{BP}$ & protein amino acid ADP-ribosylation & $1.11 \times 10^{-3}$ & 2 \\
\hline & & GO-BP & signal transduction & $1.37 \times 10^{-3}$ & 29 \\
\hline & & GO-BP & esicle-mediated transport & $1.69 \times 10^{-3}$ & 11 \\
\hline & & GO-BP & system development & $1.93 \times 10^{-3}$ & 14 \\
\hline & & GO-BP & cell surface receptor linked signal transduction & $4.81 \times 10^{-3}$ & 16 \\
\hline \multirow{10}{*}{$\begin{array}{l}\text { IL-6 (Inflammatory and } \\
\text { immune adipokines) }\end{array}$} & GOM (3) & GO-BP & immune system process & $6.66 \times 10^{-4}$ & 21 \\
\hline & \multirow[t]{9}{*}{ IAD (11) } & GO-BP & response to stimulus & $7.72 \times 10^{-4}$ & 16 \\
\hline & & GO-BP & response to interferon-gamma & $2.08 \times 10^{-3}$ & 4 \\
\hline & & GO-BP & cellular defense response & $4.67 \times 10^{-3}$ & 6 \\
\hline & & GO-BP & immune response & $6.84 \times 10^{-3}$ & 8 \\
\hline & & $\mathrm{GO}-\mathrm{BP}$ & DNA recombination & $1.06 \times 10^{-2}$ & 3 \\
\hline & & GO-BP & nitrogen utilization & $1.16 \times 10^{-2}$ & 1 \\
\hline & & $\mathrm{GO}-\mathrm{BP}$ & gluconeogenesis & $1.35 \times 10^{-2}$ & 2 \\
\hline & & GO-BP & $\begin{array}{l}\text { antigen processing and presentation of peptide or } \\
\text { polysaccharide antigen via MHC class II }\end{array}$ & $1.81 \times 10^{-2}$ & 2 \\
\hline & & KEGG & T cell activation & $1.84 \times 10^{-2}$ & 4 \\
\hline \multirow[t]{9}{*}{$\begin{array}{l}\text { TNF- } a \text { (Inflammatory and } \\
\text { immune adipokines) }\end{array}$} & \multirow[t]{9}{*}{ MAD (2) } & GO-BP & $\begin{array}{l}\text { antigen processing and presentation of peptide or } \\
\text { polysaccharide antigen via MHC class II }\end{array}$ & $4.26 \times 10^{-5}$ & 4 \\
\hline & & GO-BP & antigen processing and presentation & $6.56 \times 10^{-4}$ & 4 \\
\hline & & KEGG & T cell activation & $1.37 \times 10^{-3}$ & 4 \\
\hline & & GO-BP & cellular defense response & $3.14 \times 10^{-3}$ & 6 \\
\hline & & $\mathrm{GO}-\mathrm{BP}$ & immune system process & $8.14 \times 10^{-3}$ & 17 \\
\hline & & GO-BP & tRNAaminoacylation for protein translation & $2.18 \times 10^{-2}$ & 2 \\
\hline & & KEGG & 5-Hydroxytryptamine biosynthesis & $3.17 \times 10^{-2}$ & 1 \\
\hline & & KEGG & Mannose metabolism & $3.69 \times 10^{-2}$ & 1 \\
\hline & & GO-BF & establishment or maintenance of chromatin architecture & $3.85 \times 10^{-2}$ & 4 \\
\hline \multirow{10}{*}{$\begin{array}{l}\text { PAI-1 (Inflammatory and } \\
\text { immune adipokines) }\end{array}$} & \multirow[t]{10}{*}{$\mathrm{GOM}(2)$} & $\mathrm{GO}-\mathrm{BP}$ & immune system process & $6.00 \times 10^{-15}$ & 41 \\
\hline & & GO-BP & response to stimulus & $6.31 \times 10^{-15}$ & 30 \\
\hline & & GO-BP & cellular defense response & $1.25 \times 10^{-10}$ & 15 \\
\hline & & GO-BP & immune response & $1.35 \times 10^{-10}$ & 19 \\
\hline & & GO-BP & B cell mediated immunity & $1.05 \times 10^{-7}$ & 9 \\
\hline & & GO-BP & natural killer cell activation & $4.17 \times 10^{-6}$ & 7 \\
\hline & & $\mathrm{GO}-\mathrm{BP}$ & antigen processing and presentation & $6.62 \times 10^{-6}$ & 6 \\
\hline & & KEGG & T cell activation & $2.04 \times 10^{-5}$ & 6 \\
\hline & & $\mathrm{GO}-\mathrm{BP}$ & cell surface receptor linked signal transduction & $1.52 \times 10^{-4}$ & 23 \\
\hline & & KEGG & $\begin{array}{l}\text { Inflammation mediated by chemokine and cytokine signaling } \\
\text { pathway }\end{array}$ & $3.11 \times 10^{-4}$ & 8 \\
\hline
\end{tabular}

In all tests, the unified set of co-expressed genes for different adipose depots correlated to an obesity phenotypic trait was compared with the whole known genes which were appointed as the background. $P$ values indicating significance of the overlap between various genes sets, was calculated using Benjaminicorrected modified Fisher's exact test. BP biological process, MF molecular function. 
(GEO) [accession number GSE30343]. For more information, please refer to Li et al. [3].

\section{Identification of differentially expressed genes}

We used three-way repeated-measures ANOVA $(n=3$ per breed per sex per tissue) to identified differentially expressed (DE) mRNA among six adipose tissues between sexes of three pig breeds $(P<0.05$, corrected with adjusted Bonferroni method, FDR $<0.05,1,000$ permutations), which were further analyzed using DAVID to examine whether these DE genes were enriched for specific functional catalogs (i.e. KEGG pathways and Gene Ontology-Biological Processes and -Molecular Functions $)(P<0.05$, corrected with adjusted Bonferroni method) [26].

\section{Identification of co-expressed gene modules}

To identify sets of functionally related genes in six adipose tissues, linked to the phenotypic traits, we applied a clustering method as described previously $[4,19]$ with some modifications. Spearman rank correlation coefficients were determined between all possible gene-pairs across 18 samples for each adipose tissue. The strongest correlated gene-pair was selected, and grouped together in a set that was assigned the average expression value of the two genes that constitute this set. After addition of this newly created set to the dataset, the two individual genes were removed from the data and the strongest correlation in the dataset was again selected. This resulted in either the expansion of a set already created or in the creation of a new set. We kept repeating this as an iterative process until the most significantly correlated pair was coefficient of correlation $r<0.80$. Only the sets containing 50 or more genes are kept for further analysis. The gene sets - reflecting the average expression value of the genes constituting that set - were correlated with obesity phenotypic traits using a Spearman rank correlation coefficient.

\section{Quantitative PCR}

Quantitative PCR (Q-PCR) was used to confirm the expression pattern observed in the microarray results. QPCR was performed on a CF96 Real-Time PCR Detection System (Bio-Rad) using SYBR $^{\circ}$ Green Real-time PCR Master Mix (TaKaRa, China). The PCR primer sequences are shown in Table 4. Porcine $A C T B, T B P$ and $T O P 2 B$ were simultaneously used as endogenous control

Table 4 Primers used for the Q-PCR assay

\begin{tabular}{|c|c|c|c|}
\hline Gene symbol & Primer sequence $\left(5^{\prime} \rightarrow 3^{\prime}\right)$ & Amplicon length (bp) & GenBank No. \\
\hline \multirow[t]{2}{*}{$A C T B^{*}$} & F: TCTGGCACCACACCTTCT & 114 & DQ178122 \\
\hline & R: TGATCTGGGTCATCTTCTCAC & & \\
\hline \multirow[t]{2}{*}{$T B P^{*}$} & F: GATGGACGTTCGGTITAGG & 124 & DQ178129 \\
\hline & R: AGCAGCACAGTACGAGCAA & & \\
\hline \multirow[t]{2}{*}{ TOP2B* } & F: AACTGGATGATGCTAATGATGCT & 137 & AF222921 \\
\hline & R: TGGAAAAACTCCGTATCTGTCTC & & \\
\hline \multirow[t]{2}{*}{$A C A D L$} & F: GTAAGAACAAATGCCAAGA & 103 & NM_213897 \\
\hline & R: CAGCCACTACAATCACAAC & & \\
\hline \multirow[t]{2}{*}{$A D I P O Q$} & F: GGGTCACTGTCCCTAAC & 209 & NM_214370 \\
\hline & R: GTCCTGGTACTGGTCGT & & \\
\hline \multirow[t]{2}{*}{ ADIPOR1 } & F: TGGCTGAAGGACAACGAC & 228 & NM_001007193 \\
\hline & R: CAAGAAGAACATCCCAAACAC & & \\
\hline \multirow[t]{2}{*}{ CAV3 } & F: GCATCAGCCATATCTACTCACT & 107 & NM_001037149 \\
\hline & R: CACTTCTITCCGCAGCAT & & \\
\hline \multirow[t]{2}{*}{ MDH1 } & F: TAAGGTTATCGTGGTGGG & 124 & U44846 \\
\hline & R: TGCTITAGCTCGGTTGTG & & \\
\hline \multirow[t]{2}{*}{ MDH2 } & F: CGAGGTGGTCAAGGCTAAG & 172 & M16427 \\
\hline & R: CAATGGCGTGGAGAAATAC & & \\
\hline \multirow[t]{2}{*}{ ME 1} & F: GTTGCCCTTGGTGTTGT & 212 & X93016 \\
\hline & R: GGATAAATGGTGGCTGTC & & \\
\hline \multirow[t]{2}{*}{ Insig1 } & F: TCAACCACGCCAGTGCTAA & 251 & AY336601.2 \\
\hline & R: CACGCCTCCCGAGAAGAAA & & \\
\hline \multirow[t]{2}{*}{ SCAP } & F: CGCCTGAAACAGAAATCG & 213 & XM_001924223 \\
\hline & R: TCTCCTGAGCCTCCAACA & & \\
\hline
\end{tabular}

*: ACTB ( $\beta$ actin), TBCP (TATA box binding protein) and TOP2B (topoisomerase II $\beta$ ) are the endogenous control genes. 
genes. The $2^{-\Delta \Delta \mathrm{Ct}}$ method was used to determine the relative mRNA abundance for the surveyed samples.

\section{Abbreviations}

SAT: Subcutaneous adipose tissue; VAT: Visceral adipose tissue; ULB: Upper layer of backfat; LLB: Inner layer of backfat; GOM: Greater omentum adipose; MAD: Mesenteric adipose; RAD: Retroperitoneal adipose; IAD: Intermuscular adipose.

\section{Competing interests}

The authors have declared that no competing interests exist.

\section{Authors' contributions}

MZL and XWL conceived and designed the experiment. CWZ and MZL performed the data analysis and drafted the manuscript. JDM and AAJ collected the samples and records. GQT, MMM, LZ and LB carried out the physiological, biochemical and histological studies, statistical analysis and prepared nucleic acids. CWZ and JZ performed gene expression microarray and data analysis. All authors read and approved the final manuscript.

\section{Acknowledgments}

This work was supported by grants from the National High Technology Research and Development Program of China (863 Program) (2013AA102502), the Specialized Research Fund of Ministry of Agriculture of China (NYCYTX-009), the Project of Provincial Twelfth Five Years' Animal Breeding of Sichuan Province (2011YZGG15) and the National Special Foundation for Transgenic Species of China (2011ZX08006-003).

Received: 14 March 2013 Accepted: 22 May 2013

Published: 24 May 2013

\section{References}

1. Wronska A, Kmiec Z: Structural and biochemical characteristics of various white adipose tissue depots. Acta Physiol (Oxf) 2012, 205:194-208.

2. Matsuzawa Y: The metabolic syndrome and adipocytokines. FEBS Lett 2006, 580:2917-2921.

3. Li M, Wu H, Luo Z, Xia Y, Guan J, Wang T, Gu Y, Chen L, Zhang K, Ma J: An atlas of DNA methylomes in porcine adipose and muscle tissues. Nat Commun 2012, 3:850-861.

4. Li M, Wu H, Wang T, Xia Y, Jin L, Jiang A, Zhu L, Chen L, Li R, Li X: Comethylated genes in different adipose depots of pig are associated with metabolic, inflammatory and immune processes. Int J Biol Sci 2012, 8:831-837.

5. Karastergiou K, Smith SR, Greenberg AS, Fried SK: Sex differences in human adipose tissues-the biology of pear shape. Biology of Sex Differences 2012, 3:13.

6. Deurenberg P, Deurenberg-Yap M: Differences in body-composition assumptions across ethnic groups: practical consequences. Curr Opin Clin Nutr 2001, 4:377-383.

7. Lunney JK: Advances in swine biomedical model genomics. Int J Biol Sci 2007, 3:179-184

8. Mueller-Ortiz SL, Drouin SM, Wetsel RA: The alternative activation pathway and complement component $\mathrm{C} 3$ are critical for a protective immune response against Pseudomonas aeruginosa in a murine model of pneumonia. Infect Immun 2004, 72:2899-2906.

9. Abdelnoor AM, Kobeissy F, Farhat D, Hadi U: Circulating immune complexes and complement $\mathrm{C} 3$ and $\mathrm{C} 4$ levels in a selected group of patients with rhinitis in Lebanon. Clin Mol Allergy 2004, 2:6

10. Hoffmann SC, Schellack C, Textor S, Konold S, Schmitz D, Cerwenka A, Pflanz S, Watzl C: Identification of CLEC12B, an inhibitory receptor on myeloid cells. J Biol Chem 2007, 282:22370-22375.

11. Wolfs MG, Rensen SS, Bruin-Van Dijk EJ, Verdam FJ, Greve J-W, Sanjabi B, Bruinenberg M, Wijmenga C, van Haeften TW, Buurman WA: Co-expressed immune and metabolic genes in visceral and subcutaneous adipose tissue from severely obese individuals are associated with plasma HDL and glucose levels: a microarray study. BMC Med Genomics 2010, 3:34.

12. Wajchenberg BL: Subcutaneous and visceral adipose tissue: their relation to the metabolic syndrome. Endocr Rev 2000, 21:697-738.

13. Satoor SN, Puranik AS, Kumar S, Williams MD, Ghale M, Rahalkar A, Karandikar MS, Shouche Y, Patole M, Bhonde R: Location, location, location: Beneficial effects of autologous fat transplantation. Sci Rep 2011, 1:81.
14. Grove K, Fried S, Greenberg A, Xiao X, Clegg D: A microarray analysis of sexual dimorphism of adipose tissues in high-fat-diet-induced obese mice. Int J Obesity 2010, 34:989-1000.

15. Yuan F, Li X, Lin J, Schwabe C, Büllesbach E, Rao C, Lei Z: The role of RXFP2 in mediating androgen-induced inguinoscrotal testis descent in $\mathrm{LH}$ receptor knockout mice. Reproduction 2010, 139:759-769.

16. Luitjens C, Gallegos M, Kraemer B, Kimble J, Wickens M: CPEB proteins control two key steps in spermatogenesis in C. elegans. Genes Dev 2000 14:2596-2609

17. Joshi SG, Bank JF, Henriques ES, Makarachi A, Matties G: Serum levels of a progestagen-associated endometrial protein during the menstrual cycle and pregnancy. J Clin Endocr Metab 1982, 55:642-648.

18. Zhang H, Rakha E, Ball G, Spiteri I, Aleskandarany M, Paish E, Powe D, Macmillan R, Caldas C, Ellis I: The proteins FABP7 and OATP2 are associated with the basal phenotype and patient outcome in human breast cancer. Breast Cancer Res Treat 2010, 121:41-51.

19. Eisen MB, Spellman PT, Brown PO, Botstein D: Cluster analysis and display of genome-wide expression patterns. Proc Natl Acad Sci 1998, 95:14863-14868.

20. Smith SR, Lovejoy JC, Greenway F, Ryan D, deJonge L, de la Bretonne J, Volafova J, Bray GA: Contributions of total body fat, abdominal subcutaneous adipose tissue compartments, and visceral adipose tissue to the metabolic complications of obesity. Metabolism 2001, 50:425-435.

21. Tran TT, Yamamoto Y, Gesta S, Kahn CR: Beneficial effects of subcutaneous fat transplantation on metabolism. Cell Metab 2008, 7:410-420.

22. Iyer A, Fairlie DP, Prins JB, Hammock BD, Brown L: Inflammatory lipid mediators in adipocyte function and obesity. Nat Rev Endocrinol 2010, 6:71-82.

23. Torres-Leal FL, Fonseca-Alaniz MH, Rogero MM, Tirapegui J: The role of inflamed adipose tissue in the insulin resistance. Cell Biochem Funct 2010, 28:623-631.

24. Maury E, Ehala-Aleksejev K, Guiot Y, Detry R, Vandenhooft A, Brichard SM: Adipokines oversecreted by omental adipose tissue in human obesity. Am J Physiol-Endoc M 2007, 293:E656-E665.

25. Yim J, Heshka S, Albu J, Heymsfield S, Kuznia P, Harris T, Gallagher D: Intermuscular adipose tissue rivals visceral adipose tissue in independent associations with cardiovascular risk. Int J Obesity 2007, 31:1400-1405.

26. Da Wei Huang BTS, Lempicki RA: Systematic and integrative analysis of large gene lists using DAVID bioinformatics resources. Nat Protoc 2008, 4:44-57.

doi:10.1186/1476-511X-12-75

Cite this article as: Zhou et al: Gene expression profiling reveals distinct features of various porcine adipose tissues. Lipids in Health and Disease $201312: 75$

\section{Submit your next manuscript to BioMed Central and take full advantage of:}

- Convenient online submission

- Thorough peer review

- No space constraints or color figure charges

- Immediate publication on acceptance

- Inclusion in PubMed, CAS, Scopus and Google Scholar

- Research which is freely available for redistribution 